\title{
THE SAINT GEORGE QUARANTINE STATION OF PIRAEUS, GREECE (1865-1947)
}

\author{
KARANTENA SVETI JURAJ U \\ PIREJU, GRČKA (1865. - 1947.)
}

\author{
Anna Rosenberg,, Costas Tsiamis, ,**, \\ Effie Poulakou-Rebelakou***, Emmanuel Pikoulis" ${ }^{* * * * *}$
}

\begin{abstract}
Summary
For centuries, the marine quarantine system was the major protection of the public health against serious infectious diseases around the world. The present study reconstructs the history of the Quarantine Station of Piraeus, one of the largest Mediterranean ports, known as the "Lazaretto of Saint George", as a vital element in the maritime sanitary protection of Greece. Our research will investigate the impact left by this institution on public health, as well as on the economic life of the port of Piraeus and the adjacent capital city of Athens. With regard to the first issue, we will seek to evaluate its role in relation to major outbreaks in the capital, as well as the arrival of I.3 million Greek refugees after the Greco-Turkish War of 1922. The opening of Suez Canal (1865) was a great challenge and the institution was problematic at administrative and sanitary levels. During 20 th century, the station complied

Programme of Postgraduate Education (MSc) 'International Medicine - Health Crisis Management', Medical School, National and Kapodistrian University of Athens, Athens, Greece.

Department of Microbiology, Medical School, National and Kapodistrian University of Athens, Athens, Greece.

Department of History of Medicine, Medical School, National and Kapodistrian University of Athens, Athens, Greece.

**** $\quad$ First Surgical Department, Medical School, National and Kapodistrian University of Athens, Athens, Greece.

Correspondence Address: Costas Tsiamis, Department of Microbiology, Medical School, National and Kapodistrian University of Athens, Mikras Asias 75, Athens 115-27, Greece.E-mail: ctsiamis@med.uoa.gr.
\end{abstract}


with the national public health legislation and the international sanitary conventions. Until the Second World War, the Lazaretto of Saint George played a key role in both the protection of public health in general, but also in the economic and industrial progress of Piraeus and Athens.

Keywords: Greece, history of medicine, Lazaretto, Piraeus, public health, quarantine

\section{THE ORIgins of SANitary institutions at Piraeus}

Piraeus is the port of the Greek capital Athens and it is one of the largest ports in the Mediterranean Sea. In ancient times, it was the naval base of the powerful Athenian fleet, but during the Roman, Byzantine and Ottoman periods the impressive harbour was transformed, indeed shrunk, into a small fishing village. With the recognition of the liberation of Greece from the Ottoman Empire in 1832, Piraeus started building commercial relations with the ports of Smyrna (Izmir), Constantinople (Istanbul), Alexandria, Livorno, Trieste and Marseilles (Virvilis 2007). From 1837 onwards, the French postal steamers (Messageries Maritimes Nationales) and the ships of the Austrian Lloyd regularly moored in the port.

In 1833 , the Municipality of Piraeus was established, and a small lazaretto set up at the extremity of the harbour, with the available resources. This first lazaretto suffered from multiple functional problems that caused Piraeus to actually stay without an effective sanitary coverage for the next years. In general, the lack of the lazarettos on the territory of the Greek State was sound. In contrary, the complex of Ionian Islands in western Greece under the political status of British Protection had a strict sanitary legislation and a network of lazarettos. (Poulakou-Rebelakou et al 2004, Tsiamis et al 2018). With the establishment of British rule on the Ionian Islands (Treaty of Paris, I815), the new authorities adopted the old Venetian sanitary model of lazarettos. During the period of British presence on the islands (I8I5-I864) a new programme was launched, aimed at the re-organization and the renovation of the old Venetian lazarettos or the building of new ones (Table I). Table I. Venetian and British Lazarettos in Ionian Islands

\begin{tabular}{ccc} 
Island & Venetian Era & British Protection \\
\hline Corfu & $\begin{array}{c}\text { I588 (Sanitary Station) } \\
\text { I705 (Lazaretto) }\end{array}$ & I8I4 (renovation) \\
Cephalonia & I705 Lazaretto & I84I(renovation)
\end{tabular}




\begin{tabular}{ccc} 
Island & Venetian Era & British Protection \\
\hline Zante & I690 Lazaretto & I854(renovation) \\
Santa Maura & I718 Lazaretto & I820 c. (New lazaretto) \\
Ithaca & I560 Lazaretto & I8I7 (renovation) \\
Cerigo & Sanitary station & I8I7 (New lazaretto) \\
Paxi & Sanitary station & I820 c. (New lazaretto)
\end{tabular}

In the British Mediterranean possessions (Malta, Ionian Islands, and Gibraltar) of the $19^{\text {th }}$ century, the fear of the contagion led to strict prophylactic measures against suspicious cases in order to protect the social body of the possession and the military units. The strategy of a well-functioning public sanitary system, a welfare social policy, and the effective network of lazarettos was essential for the upholding of the public order and the "gratitude" of the natives (Chircop 20r4). On the contrary, during this period of high politics of social welfare, the tiny Greek Kingdom was at the start of a new historical period and the multilevel organization of the new state. From this point of view, the first sanitary rules in the naval transport and the organization of the first lazarettos were a real achievement.

According to the instructions of the Greek Royal Magistrate of Health passengers from Minor Asia and Syria were obliged to stay in quarantine for 17 days and passengers from Tunis for 9 days (Virvilis 2007). However, despite relevant sanitary measures and great commercial expectations, big shipping companies were unwilling to risk any connection with Piraeus, mainly due to the lack of a real lazaretto and adequate storage facilities at the port. Moreover, the cargo disinfection was inadequate in comparison to the standard procedures of other Mediterranean lazarettos (Howard I79I).

The importance of the latter derived from a belief in public health being associated with a safe exchange of merchandise defended by medical theories dominant at the time. More precisely, such belief corresponded to miasmatic and contagionistic theories during the $19^{\text {th }}$ century: the first, which stressed the direct influence of the atmospheric conditions on the rise of an infectious outbreak (miasmatic); the second, which attributed the poor sanitary conditions as a risk factor for which an outbreak could arise (contagionistic); and the third theory that combined both miasmatic and contagionistic factors (Howard 1791, Bryan 1873, Rosen 1993, Barnes 2014). 
In 1845 , the Greek parliament passed an Act regulating the establishment and the operations of the lazarettos (Gazette of the Government, 1845). Unfortunately, the lazaretto remained ineffective, and the port completely unprotected and vulnerable to cholera, which was the most feared epidemic disease in the Mediterranean during most of the $19^{\text {th }}$ century. The disease reached out from the Indian subcontinent to Central Asia, the Far East and spread worldwide via terrestrial and maritime routes. Commercial exchanges, military campaigns, and religious pilgrimages contributed greatly to its rapid spread. Cholera spread to the Mediterranean from the period of the second pandemic (I827-35) until the fifth pandemic (I88I-96), with the disease entering the region either directly through the Middle East or indirectly via North Africa (Hays 2005). During the third pandemic, in the context of the large military and naval operations of the Crimean War (1853-1856, French, British and Ottoman Empires against Russian Empire), cholera was brought to Piraeus, in 1854 , by the French troops. The quarantine system collapsed in Piraeus, a large-scale epidemic affected the area, and more than I,ooo deaths were recorded in Athens and Piraeus (Korasidou 1995).

During the $19^{\text {th }}$ century it was often difficult to calculate the mortality rates of cholera pandemics in Mediterranean countries. Complex religious, social and urban factors conditioned the final number of casualties in every country, city and port. Approximately 220 outbreaks occurred in the Mediterranean region (in the coastal areas and mainland). The mortality showed no significant difference between the Eastern and Western Mediterranean regions ranging from $56 \%$ to $60 \%$. A possible explanation of this 'mirror effect' between the east and the west is the phylogenetic identity of the microorganism (Vibrio Cholerae Or Classical biotype) (Siddique, Cash 20r4). Unfortunately, the lazaretto of Piraeus proved inadequate to protect the city from such deadly disease, similarly to what was happening with various other lazarettos around the Mediterranean.

The period of cholera pandemics is characterized by the international mobilization through the International Sanitary Conferences (1851-1897, the International Sanitary Convention of Venice in 1892) and the attempt of establishment of common international health regulations. In addition, the duration of quarantine for various infectious diseases was not common in the Mediterranean. Indicatively, we mention the cases of the Ionian Islands under British Protection and the rest of Greece. According to the Greek Sanitary Law (1845) the duration of quarantine was upon the decision of the Health Services. Similarly, on the Ionian Islands the duration of 
the quarantine ranged from 9 to 40 days. In case of contact with another ship while at sea, the ship having departed from a port where an epidemic had broken out, another 24 days of isolation were added (Tsiamis 20I8). In I86r, the British Administration of the islands in collaboration with the Medical Society of Corfu defined the duration of quarantine (plague 40 days, smallpox I2 days, cholera 9 days and yellow fever 40 days) (Report 186I).

The International Sanitary Conferences had particular effect on the national health legislations of the Mediterranean states. This fact affected the organization of the lazarettos. A typical example is the case of Spain with the transfer of health control of sanitary cordons, from the local (coastal) to the central (inland) authorities (Bonastra 2018, Pujadas-Mora 2018).

\section{The Lazaretto of Saint George: Trade And disease near the Suez Canal}

The opening of the Suez Canal in I869 cut the distance to Asia by connecting the Mediterranean to the Red Sea (Sichko 20II). In the years immediately preceding the opening of the Suez Canal, the port of Piraeus emerged as a key intermediate refuel station on the main Mediterranean sea-routes connecting Europe with the East. The shipyards of Piraeus were used to repair the European steamers. Also, the Greek traders had an opportunity to expand their activities in India with new commercial branches. At the end of the $19^{\text {th }}$ century, the Greek companies in India had more than Io,, 00 workers (Chasiotis et al 2006).

This also made the port more vulnerable to the rapid transmission of infectious diseases circulating between Europe, Africa and Asia. This led the Greek authorities to organize a new, permanent lazaretto outside the harbor. They opted for the small island of Saint George, located one mile away, close to the bigger and better-known island of Salamina (Salamis), a site of the famous naval battle that took place during the Greco-Persian Wars of the $5^{\text {th }}$ century BC. Saint George has a surface of 9 acres and is at present connected to Salamina by a small bridge. Before the establishment of the lazaretto, and since the great cholera epidemic of 1854 , a small sanitary station had been in operation. The bay located opposite St. George in Salamina Island had also been used as a mooring site for ships undergoing clearance and disinfection procedures, while the crews spent their quarantine in the port of Piraeus.

In 1865 , when, for the first time, cholera threatened to penetrate Europe directly by the sea from Egypt, as it would finally do, the small station on Saint 
George was transformed into the official Lazaretto of the port of Piraeus. The Lazaretto was essentially a cluster of houses for the isolation of patients and suspicious cases. There were a total of 20 pavilions divided into Io pairs of houses. There was no drinking water on the islet of Saint George, as in Salamis, and the Greek authorities had to send barrels of fresh water from Piraeus on a daily basis. According to the country of origin of every ship or the port of its departure, the duration of the quarantine lasted between 5 days, from western ports of Italy and France, and 15-20 days from the ports of Egypt and Turkey. Actually, the ports of the Eastern Mediterranean were characterized as "suspicious or unprotected ports" (Article 3, paragraphs 2,3/ Sanitary Law and sanctions, Gazette of the Government 3I, 7 Dec. 1845.).

Following the Greek Quarantine Regulations of I845, the Lazaretto did not provide free housing. For decades, Greek newspapers were rife with letters of protest written by Greek and foreign travelers who complained about the excessive cost, the poor conditions of living and the overall mismanagement of the institution. A German traveler confined there in 1884 wrote: "What kind of quarantine is this? The cook is all day with us, and every day he goes to Piraeus for supplies!" (Virvilis 2007). As a result of so many protests, the Greek government decided to take over the running expenses of the quarantine station, to allow a free stay for the most deprived individuals and to align the prices of the quarantine lodges with the prices of B-class hotel rooms in Piraeus and Athens. Based on the data we have gathered on the total public health budget, expenditure on lazarettos and quarantine services between 1835 and I9II, it seems that the latter category represented the largest proportion of the total public expenditure on public health (Ithakisios, Vozikis 20I4).

The year 1882 marked the first serious "crash-test" for the new lazaretto. The early isolation of patients in this lazaretto during a smallpox outbreak in the industrial district of Piraeus saved both Piraeus and Athens from being seriously struck (Gouzaris I882). In I880's, the newspapers expressed the view that Saint George was located at an extremely dangerous point as the Lazaretto was near to the base of the Greek Army Navy. Also, according to other opinions, Saint George was near to the city of Piraeus and, most importantly, so close to Athens. According to the newspapers, for a lazaretto so close to the capital, "the temptations of violation of health regulations from the visitors are great" (Virvilis 2007). There were actually many cases of people under quarantine escaping from Saint George. One most interesting case was recorded in 1867, when the famous American author Mark Twain 
recorded his getaway from this lazaretto, in his book "The new pilgrim's progress". Together with two friends of his, Twain escaped from Saint George's quarantine and arrived in the capital city, where they bribed the guard of the Acropolis in order to enjoy the view of Athens from the ancient temple of Parthenon. In this adventure, according to Twain's somewhat fictional account, it was far more difficult to escape from a dog that chased them after they stole some fruits from a garden than from the guards of the lazaretto and the policemen in Athens (Twain I869).

In the early period after the opening of the Suez Canal, it soon became clear that quarantine in the Piraeus was essentially a product of a compromise between the financial and commercial interests and those emphasizing the defense of public health (Ithakisios, Vozikis 20I4, Rosenberg 1966, Roberts, 200I). The existence and effectiveness of the Lazaretto was actually one of the major factors that contributed to the increasing maritime and commercial traffic of Piraeus. Such economic development would be followed by a substantial demographic growth and a strong process of industrialization of the city. It is worth mentioning that at the end of the $19^{\text {th }}$ century, $71 \%$ of the horsepower of all Greek industry was concentrated in Piraeus, and that $48 \%$ of all Greek workers, and $66 \%$ of all industrial workers were employed there (Pardali-Lainou 1990).

\section{EPIDEMICS, COMMERCE AND MIGRANTS DURING THE $20^{\mathrm{TH}}$ CENTURY}

The increasing size and complexity of the Lazaretto at Piraeus in the decades following its establishment was matched by a parallel expansion of the port's functions. The re-organization and improved safety of the sanitary premises secured more shipping and exchanges in goods and hence increased income. Indicative of this is the fact that in 1900 Piraeus was ranked in the eighth place (with 3,023,615 tons of merchandise being handled) among all European ports $\left(8^{\text {th }}\right.$ after London, Hamburg, Antwerp, Rotterdam, Liverpool, Marseilles, and Genoa). By I9I3, Piraeus had shot up to the fourth place on this same list of the Mediterranean ports (Pardali-Lainou 1990). However, in IgII cholera epidemic broke out in Turkey, which rapidly reached Italy. This led the Greek health authorities to make ready two lazarettos for an eventual emergency: one in the port of Corfu (western Greece) for ships arriving from the Western Mediterranean region, and the other being the Lazaretto of Saint George for ships coming from the Eastern Mediterranean. According to the instructions implemented by the state health authorities, 
the staff at the Saint George's lazaretto was to be composed of three military physicians, three nurses, four disinfectors, one police officer and six soldiers. The quarantine lodges were to be categorized in this way: A- (two beds in every room); B- (three beds) and C-class ( $15-20$ beds per room). The disinfectants used at the time were formalin of $40 \%$ concentration, ammonia $(25 \%)$, carbolic acid, powdered mercury, lime and alcohol (Virvilis 2007).

The next milestone in the history of the Lazaretto was its use for the isolation of the Greek refugees that fled Southern Russia during the years of the Russian Civil War (1919-20). The Greek government sent troops to this conflict in order to support the French and British armies in their campaign against the Bolsheviks in the Crimea (Kim I98I, Moffat 20I5). With the defeat of the Allies, the local Greek communities that had been settled for centuries in Southern Russia and the Caucasus were forced to flee the country. Under the intense pressure brought about by the waves of refugees, the Greek government was obliged to put the lazarettos of Piraeus and Thessaloniki to use as the immigration control gates into Greece. The major diseases of the Greek refugees, in both Quarantine Stations of Athens and Thessaloniki, were enteritis, dysentery, typhus, and malaria (Anoyatis-Pelé, 2015). All suspected cases being successfully isolated in the Lazaretto of Saint George. Table 2. Infectious diseases among Greek refugees for Russia, I919-I920.

(Data from the Quarantine Station of Thessaloniki)

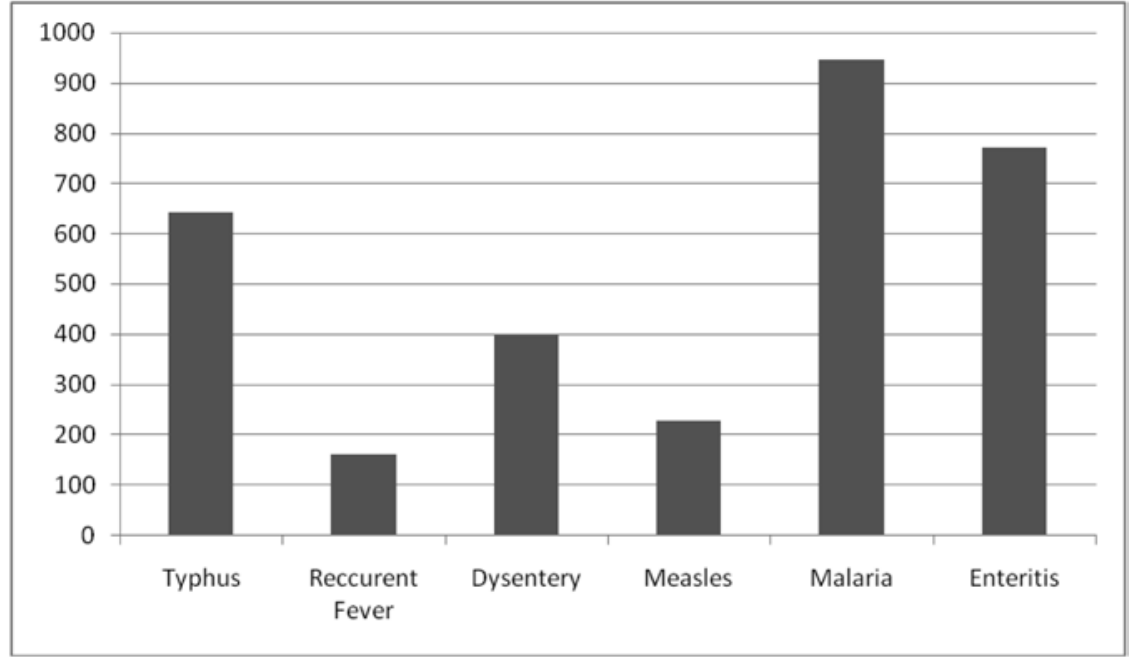

The lazaretto would also be used for the isolation of the Greek war prisoners during the First World War (Kopanaris 1933). By the end of this 
conflict, some 6,500 Greek soldiers stayed in the quarantine at Saint George after their return to Greece from the German concentration camps in Poland. Typhoid fever was the major disease affecting soldiers (Vournas 1997).

The climax of the lazaretto as an entry point during the early decades of the $20^{\text {th }}$ century would, in any case, be the arrival of $1.300,000$ refugees following the defeat of Greece in the Greek-Turkish War of I92I-22. The ensuing Treaty of Lausanne of 1923 imposed the compulsory exchange of the Christian and Muslim populations of Thrace and Minor Asia between Greece and Turkey. Almost 20\% of the Greek refugees entered the country through the lazaretto of Piraeus, and the rest via the lazaretto at Thessaloniki and a number of other sanitary stations along the country's borders.

Table 3. Arrivals of refugees in Piraeus (one month after the Disaster of Smyrna, 1922). (Dates according to the Old Style Greek Calendar)

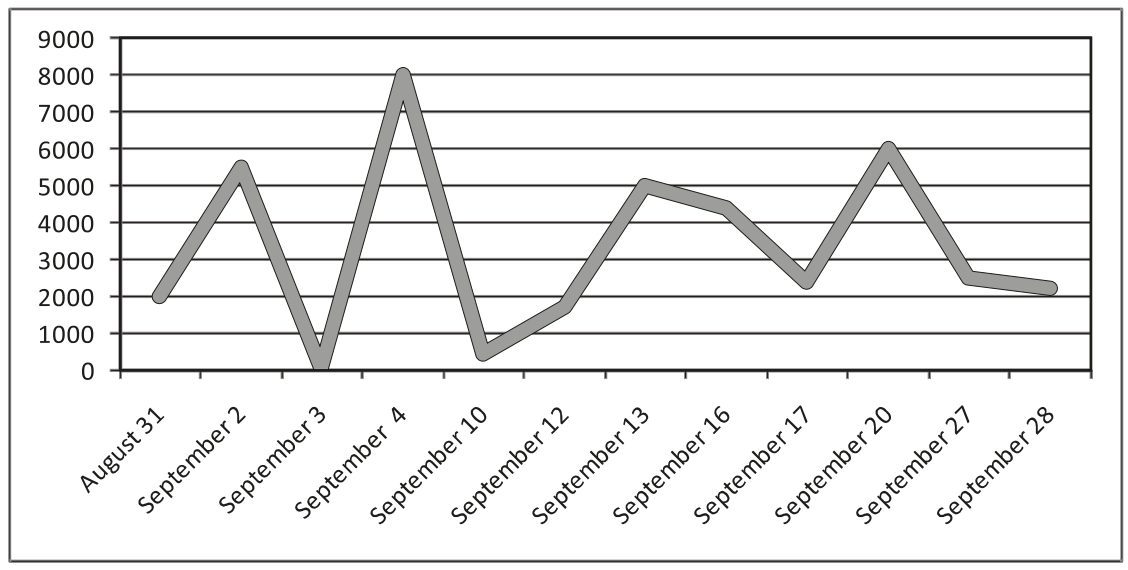

The first ships carrying refugees anchored in front of Saint George as the sanitary officers started examining the passengers for symptoms of typhoid fever and cholera. Before finally disembarking in Piraeus and Athens, over I00,000 patients or 'suspect cases' underwent quarantine at Saint George. (Kitromilidis, Mourelos 2004). After the arrival of the last waves of refugees in 1924, every month almost 8,000 persons underwent their quarantine (April to August), 16,000 from September until the end year (Kopanaris 1933).

From a sanitary point of view, the interwar period would see the Lazaretto associated with the new Port Health Office (1930), whose mission was to implement the sanitary control of all travelers, crews and imported animals. The diseases that posed the greatest risk at the time were cholera, yellow 
fever, smallpox, plague, and typhus. The "blacklist" of the Lazaretto of Saint George was filled with names of passengers from Syria, Iraq, Persia, India, French Indochina, China, Egypt, Algeria and Tunisia. Suspicious passengers who arrived through the new airport built near Piraeus (1938) were also held at Saint George for quarantine, in compliance with the regulations put in force by the International Aviation Hygienic Convention of Hague of 1933, which Greece had endorsed (Tsiamis et al 20I4). According to the port's archival records, during the interwar period the number of passengers increased from 567,000 passengers in the early 1920 s to 811,000 in the early I930s. The quarantine station continued to provide for a variety of services, thus contributing to the economic and shipping development of Piraeus as a sanitary safe port. The new frame of global navigation and trade would bring about a re-organization of the port's functioning. In 1930 the Law 4748/30 "On Organization of port of Piraeus" established the Piraeus Port Authority, though the ultimate aim was the designation of the port as a Free Trade Zone (Pardali-Lainou 1990). The custom supervision, the management, the inspection, and the effective quarantine system were some of the major points for the declaration of a Free Trade Zone. In this context, the excellent functioning of the Lazaretto, in line with the other services of the port, had a positive impact on the final decision. On the $22^{\text {nd }}$ February 1932, the port of Piraeus was classified as a Free Trade Zone (Pardali-Lainou 1990).

During the Second World War, despite the frequent and massive air raids against the adjacent Salamis naval base, the Saint George lazaretto remained intact. After the war, the Lazaretto would remain open until 1947, when its operation ceased ones and for all. The last recorded use of the Lazaretto took place in October and November of that year as 620 passengers arrived by sea and 42 by air from Egypt, where a cholera epidemic had recently broken out. From 1947 until the early I960's, the Lazaretto operated as a unit of the Public Psychiatric Hospital of Athens ("Asylum of Saint George"), thus coming to be known as the "Island of Madness". Today, the access to the place is forbidden, as the islet belongs to the station of the Greek Army Navy. 


\section{Conclusion}

The Quarantine Station of Saint George belonged to the health services of the port of Piraeus for nearly a century. Until the end of the $\mathrm{r}^{\text {th }}$ century its actual performance was problematic at both the administrative and sanitary levels, a factor which prevented the further commercial, industrial and demographic development of the city following the opening of the Suez Canal. With the turn of the century and during the interwar period, the sanitary complex finally complied with the national public health legislation and the international sanitary conventions. No epidemic arriving by maritime routes during the $20^{\text {th }}$ century, while the victims and suspect cases of land outbreaks (especially the cholera cases of I9I7 and I9I9) were successfully isolated and treated on Saint George. In 1923, the quarantine of 100,000 Greek refugees arriving from Turkey, which was performed within a few months and occurred with a complete absence of outbreaks in Athens and Piraeus, proved to be a tour de force for the Greek Health Authorities. In sum, one can conclude by saying that Saint George played a key role in both the protection of public health in general, but also in the economic and industrial progress of Piraeus and Athens until the Second World War. 


\section{REFERENCES}

1. Anoyatis-Pelé, D., Athanasopoulou, I.,Tsiamis, C. 2015, Demographic and Medical Study of the Nosological Spectrum of Greek Refugees from Southern Russia (1919-1920). Mediterranean Chronicles 5, pp. 197-212.

2. Barnes, D. 2014, Cargo, "infection", and the logic of quarantine in the nineteenth century. Bulletin of History of Medicine 88 (1), pp. 75-101.

3. Bonastra Q. 2018, Quarantine and territory $n$ Spain during the second half of the nineteenth century. In: J. Chircop, F. Javier-Martiñez (eds). Quarantines: Space, Identity and Power in Mediterranean, 1780-1914.Manchester University Press, Manchester, pp. 17-46.

4. Bryan, J. 1873, The origin of miasmatic disease, British Medical Journal, pp. 688-689.

5. Chasiotis, J., Katsiardi-Hering, O., Abatzi, E. 2006, The Greeks of Diaspora (15 ${ }^{\text {th }}$ $21^{\text {th }}$ centuries), Editions of Hellenic Parliament, Athens, pp. 65-67.

6. Chircop J. 2014, Public Health and Poor-relief in the British Mediterranean Colonial context, 1800-1860s,. In L. Abreu (ed), European Health and Social Welfare Policies, Blansco, Lisbon, pp. 299, 307, 315-320.

7. Gazette of the Government 1845, Sanitary Laws and sanctions/31/1845. 1. Operations of the lazarettos, 2. On Sanitary Services, 3. On Assessment of Sanitation and Quarantine., Athens 7 December, f31.

8. Gouzaris, S. 1882, The epidemic of smallpox in Piraeus. Presentation in Athens Medical Society, Athens 13 February 1882.

9. Hays, J. 2005, Epidemics and Pandemics: their impacts in human history. Clio, California, pp. 193-200, 211-238, 267-280, 303-314, 345-354.

10. Howard, J. 1791. An Account of the Principal Lazarettos in Europe; with Various Papers Relative to the Plague: Together with Further Observations on some Foreign Prisons and Hospitals; and Additional Remarks on the Present State of Those in Great Britain and Ireland. J. Johnson, London, pp. 20-21.

11. Ithakisios, D., Vozikis, A. 2014, Quarantine and Lazarettos in the $19^{\text {th }}$ century Greece: An economic Perspective. Journal of Economics and Business, 64(1), pp. $42-52$.

12. Kim, M. 1981, The French army and intervention in Southern Russia, 19181919. Cahiers du monde russe et soviétique, 22(1), pp. 43-66.

13. Kitromilidis, P., Mourelos, G. 2004, Exodus-narrations of the central and south provinces of Minor Asia. Vol.2. Center of Minor Asia Studies/Onassis Foundation, Athens (personal narrations from the quarantine in Saint George pp.8, 11, 18, 2, 22, 31, 57, 96, 116, 127, 161, 168, 181, 204, 260, 263, 471).

14. Kopanaris, F. 1933, Public Health in Greece-Proceedings of the Directorate of Health, Ministry of Hygiene, Athens, p. 39. 
15. Korasidou, M. 1995, The miserables of Athens and their healers: poverty and philanthropy in the Greek capital during $19^{\text {th }}$ century. Center of Greek Studies /National Hellenic Research Foundation, Athens, pp. 104-119.

16. Moffat, I. 2015, The Allied Intervention in Russia, 1918-1920: The Diplomacy of Chaos, New York, pp. 165-186.

17. Pardali-Lainou, A. 1990, The evolution of the port of Piraeus and the impact to economic development of the area of Piraeus (1835-1985), Doctoral Thesis, Panteion University of Social and Political Sciences, Athens, pp. 118-132, 152-159.

18. Poulakou-Rebelakou E., Tsiamis C., Tompros N. 2004, Travellers' impressions from the Ionian Islands lazarettos during the British Protection (1815-1864), Proceedings of $39^{\text {th }}$ International Congress on the History of Medicine, Bari, pp. 38-45.

19. Pujadas-Mora J., Salas-Vives P. 2018, Inland sanitary cordons and liberal administration in Southern Europe: Mallorca (Balearic Islands), 1820-70. In: John Chircop, Francisco Javier-Martiñez (eds).Quarantines: Space, Identity and Power in Mediterranean, 1780-1914. Manchester University Press, Manchester, pp. 280-299.

20. Report of the Central Medical Society of Corfu to H. Drummont Wolff, Secretary of H.M. Lord High Commissioner, Corfu 24 March 1861.

21. Roberts, D. 2001, The integration of economics into SPS risk management policies: issues and challenges, in K. Anderson, CH. McRae, D. Wilson (eds) The economics of quarantine and the SPS agreement, C.I.E.S. \& AFFA Biosecurity Australia, University of Adelaide Press, pp. 9-28.

22. Rosen, G. 1993, A History of Public Health. The Johns Hopkins University Press, Baltimore, pp. 263-266.

23. Rosenberg, C. 1966, Cholera in $19^{\text {th }}$-century Europe: a tool for social and economic analysis. Comparative Studies in Society and History, 8 (4), pp. 452-463.

24. Sichko, C. 2011, The influence of the Suez Canal on Steam Navigation, University of Colorado, Colorado, pp. 3-5.

25. Siddique, A., Cash, R. 2014, Cholera outbreaks in the classical biotype era. Current Topics in Microbiologic Immunology, 379, pp.1-16.

26. Tsiamis, C., Vrioni, G., Poulakou-Rebelakou, E., Androutsos, G., Tsakris, A. 2014, Import infectious diseases control in Greece: from Interwar to the Postwar Europe. Acta Microbiologica Hellenica, 59(2), pp. 43-56.

27. Tsiamis C., Thalassinou E., Poulakou-Rebelakou E., Hatzakis A. 2018, Effectiveness of quarantine system in the Public Health of the Ionian Islands during the period of British Protection (1815-1864). In: John Chircop, Francisco Javier-Martiñez (eds).Quarantines: Space, Identity and Power in Mediterranean, 1780-1914. Manchester University Press, Manchester, pp. 256-279. 
28. Twain, M. 1869, The innocents abroad: or the new pilgrim's progress, The American Publishing Company, Connecticut, pp. 340-349.

29. Virvilis, A. 2007, The Lazaretto of Saint George of Salamis. Proceedings of the Workshop on the History of the lazarettos and the Boards of Health in Greece. Army Navy Hospital of Salamis, Salamis, pp. 107-116.

30. Vournas, T., History of Modern Greece.vol.2, Ed. Pataki, Athens, p. 208.

\section{SAŽETAK}

Stoljećima je morski karantenski sustav bio glavna zaštita javnog zdravlja od ozbiljnih zaraznih bolesti širom svijeta. Ovo istraživanje rekonstruira povijest karantene u Pireju, jednoj od najvećih mediteranskih luka, poznatoj pod nazivom Lazaret svetog Jurja, kao bitnog elementa pomorske sanitarne zaštite Grčke. Naše istraživanje proučit će utjecaj ove institucije na javno zdravstvo te gospodarski život luke Pirej $i$ susjednoga glavnog grada Atene. Uz to, nastojat ćemo procijeniti ulogu lazareta u odnosu na velike epidemije u glavnom gradu te pri dolasku I,3 milijuna grčkih izbjeglica nakon Grčko-turskog rata I922. Otvaranje Sueskog kanala (I865.) značilo je velik izazov, a djelovanje institucije bilo je problematično na administrativnoj i sanitarnoj razini. Tijekom 20. stoljeća ustanova se uskladila s nacionalnim javnozdravstvenim zakonodavstvom $i$ medunarodnim sanitarnim konvencijama. Do Drugoga svjetskog rata Lazaret sv. Jurja imao je važnu ulogu u zaštiti javnog zdravstva općenito, kao i u gospodarskom i industrijskom razvoju Pireja i Atene.

Ključne riječi: Grčka; povijest medicine; Lazaret; Pirej; javno zdravstvo; karantena 